\title{
Impact of Projected Climate Change on Summer Mungbean in Gujarat, India
}

\author{
B.I. Karande, H.R. Patel, S.B. Yadav*, M.J. Vasani and D.D. Patil \\ Department of Agricultural Meteorology, B.A. College of Agriculture, Anand Agricultural \\ University, Anand, Gujarat, India \\ *Corresponding author
}

\section{Keywords}

Mugbean, PRECIS, simulation, DSSAT, Projected climate

Article Info

Accepted:

22 July 2018

Available Online:

10 August 2018

\section{A B S T R A C T}

The experimental data collected at Anand station (Latitude $22^{\circ} 35^{\prime}$, Longitude $72^{\circ} 55^{\prime}$, altitude 45.1 MSL) during the year 2015 and 2016 for various irrigation levels, varieties and spacing $\left(\mathrm{I}_{1^{-}} 0.8 \mathrm{IW} / \mathrm{CPE}\right.$ ratio, $\mathrm{I}_{2^{-}} 0.6 \mathrm{IW} / \mathrm{CPE}$ ratio, $\mathrm{I}_{3^{-}} 0.4 \mathrm{IW} / \mathrm{CPE}$ ratio, $\mathrm{V}_{1^{-}}$Meha, $\mathrm{V}_{2^{-}} \mathrm{GM}-4, \mathrm{~S}_{1}-45 \mathrm{~cm}$ row to row spacing $\mathrm{S}_{2^{-}} 30 \mathrm{~cm}$ row to row spacing). Were used to calibrate and validate the model. The quantification of the impact of projected changes in climatic parameter such as atmospheric $\mathrm{CO}_{2}$, temperature and rainfall on mungbean crop production was assessed using validated DSSAT4.6 (CROPGRO) model for Anand districts of Gujarat. The normal daily BSS data was used in the model. The DSSAT (CROPGRO) model was used to simulate the phenology and yield and yield attributes using daily data of baseline (1961-1990) and projected period (2071-2100). Possible effects of climate change on plant growth were evaluated using the crop growth simulation model. Projected $\mathrm{CO}_{2}$ concentration and temperature projections were applied as climate change study. The PRECIS outputs for the $\mathrm{A}_{2}$ - scenarios (2071-2100) indicated that the mean maximum, minimum temperature and rainfall are expected to increase by 4.6 to 4.3 ${ }^{0} \mathrm{C}$ and $402 \mathrm{~mm}$ respectively at Anand district. Results revealed that the reduction in anthesis days may be highest (16.1\%) in treatment $\mathrm{I}_{3} \mathrm{~V}_{2} \mathrm{~S}_{2}$ and lowest $(5.7 \%)$ in treatment $\mathrm{I}_{1} \mathrm{~V}_{1} \mathrm{~S}_{1}$, However the duration of days to physiological maturity are projected to be reduced, in all treatments of green gram. However the reduction may be highest (23.8\%) in treatment $I_{3} V_{2} S_{2}$ and lowest (10.5\%) in treatment $I_{1} V_{1} S_{2}$. The grain yield reduction due to impact of climate change ranged 7.5 per cent to 21.3 per cent at different treatment. The highest yield reduction was projected in $\mathrm{I}_{3} \mathrm{~V}_{2} \mathrm{~S}_{2}$ and lowest was projected in $\mathrm{I}_{1} \mathrm{~V}_{1} \mathrm{~S}_{2}$, while mean yield reduction was $7.5 \%$.

\section{Introduction}

The most important variable in climate change is temperature. One of the major effects of increases in temperature is to speed up the period of growth of the crop, especially in the grain-filling stage, resulting in lower yields. This effect is especially pronounced in semitropical and tropical conditions, since in these areas many crops are already at the outer limits of the temperatures that they can tolerate. Other significant consequences of increased temperatures include increase in the transpiration rate and accelerated loss of soil moisture, both of which increase the water demand of a crop. The daily maximum temperatures in Gujarat during summer season are frequently exceeding $39^{\circ}$ to $40^{\circ} \mathrm{C}$, which 
are at tolerance limit of the mungbean. Therefore, rise in temperature by few degrees will severely affect growth and yield of summer mungbean. Using PRECIS model output as per IPCC scenario the rise of temperature for Anand was calculated for period 2071 -2100 AD. This daily PRECIS model output for different weather parameters viz., maximum temperature, minimum temperature and carbon dioxide were used as input for CROPGRO model and simulated effects of rise in maximum temperature, minimum temperature and carbon dioxide on summer mungbean growth and yield. The CROPGRO model simulated results were compared with baseline output of model for impact of climate change study. According to the UKMO Climate change induced by increasing greenhouse gases is likely to affect crops differently from region to region, on an average crop yield is expected to drop down to $50 \%$ in Pakistan and India (Schneider, 2007). Cline (2008) studied how climate change might affect agricultural productivity in the 2080s. His study assumed that no efforts are made to reduce anthropogenic greenhouse gas emissions, leading to global warming of $3.3{ }^{0} \mathrm{C}$ above the pre-industrial level. He concluded that global agricultural productivity could be negatively affected by climate change with the worst effects in developing countries.

Lobell et al., (2008) assessed how climate change might affect 12 food-insecure regions in 2030. The purpose of their analysis was to assess where adaptation measures to climate change should be prioritized. They found that without sufficient adaptation measures, South Asia and South Africa would likely suffer negative impacts on several crops which are important to large food insecure human populations. The effect of projected climate change for winter wheat production was simulated by Kersebaum et al., (2008) for 9 sites across Germany using the dynamic agro- ecosystem model HERMES and down scaled climate change scenarios of GCM ECHAM5 output for SRES emission scenario A1B until 2050. Yield reductions between 2 and $11 \%$ were estimated for 8 sites during the period 2031-2050. At higher altitude one site showed an increase in simulated grain yield compared to the reference period 1970-1989. Yield reduction was greatest on sandy sites and dry eastern parts of Germany.

Yadav et al., (2012) using Info Crop-wheat model reported that grain yield of two cultivars (GW-322 and GW-496) of wheat at Anand during (2071-2100) period would be 56 and $61 \%$ less than current yield levels which would be mainly due to increasing minimum and maximum temperatures during projected period.

Singh et al., (2014a) investigated the impacts of climate change by using CROPGROGroundnut model on productivity of groundnut at three sites (Anantapur, Mahboobnagar and Junagadh) and found that at Anantapur changes in temperature and rainfall by 2030 and 2050 decreased the pod yield by $13 \%$ and $20 \%$ respectively. At Mahboobnagar change in temperature and rainfall significantly decreased the pod yield by 8 and $11 \%$ by 2030 and 2050 and at Junagadh change in temperature and rainfall significantly decreased the pod yield by 2 and $7 \%$.

Singh et al., (2014b) investigated the impacts of climate change on the productivity of chickpea (Cicer arietinum L.) at selected sites in South Asia (Hissar, Indore and Nandhyal in India and Zaloke in Myanmar) and East Africa (DebreZeit in Ethiopia, Kabete in Kenya and Ukiriguru in Tanzania). As compared to the baseline climate, the climate change by 2050 (including $\mathrm{CO}_{2}$ ) increased the yield of chickpea by $17 \%$ both at Hissar and Indore, $18 \%$ at Zaloke, $25 \%$ at DebreZeit and $18 \%$ at 
Kabete; whereas the yields decreased by $16 \%$ at Nandhyal and $7 \%$ at Ukiriguru. The yield benefit due to increased $\mathrm{CO}_{2}$ by 2050 ranged from 7 to $20 \%$ across sites as compared to the yields under current atmospheric $\mathrm{CO}_{2}$ concentration while the changes in temperature and rainfall had either positive or negative impact on yield at the sites. Yield potential traits (maximum leaf photosynthesis rate, partitioning of daily growth to pods and seed-filling duration each increased by 10\%) increased the yield of virtual cultivars up to $12 \%$. Yield benefit due to drought tolerance across sites was up to $22 \%$ under both baseline and climate change scenarios. Heat tolerance increased the yield of chickpea up to $9 \%$ at Hissar and Indore under baseline climate, and up to $13 \%$ at Hissar, Indore, Nandhyal and Ukiriguru under climate change.

$\mathrm{Fu}$ et al., (2016) studied the changes in yield in relation to combined effects of $\mathrm{CO}_{2}$, temperature and precipitation by CROPGROSoybean model and observed that yield was projected to decrease under the climate combination including the extremely high temperature of $+7.4{ }^{0} \mathrm{C}$ and yield increased due to elevated $\mathrm{CO}_{2}$ and precipitation.

\section{Materials and Methods}

\section{Climate change projection under $\mathbf{A}_{2}$ scenario for Anand}

Using PRECIS model output as per IPCC scenario the rise of temperature for middle Gujarat was calculated for period $2071-2100$ AD. This daily PRECIS model output for different weather parameters viz., maximum temperature, minimum temperature, rainfall and carbon dioxide were used as input for CROPGRO model to run model and simulated effects of rise in maximum temperature, minimum temperature and carbon dioxide on summer mungbean growth and yield were evaluated. The CROPGRO model simulated was compared with baseline output of model to find out impact of climate change on summer mungbean.

The PRECIS projection output of scenario $\mathrm{A}_{2}$, and baseline were considered for projection of weather for 2071 to 2100 . As the baseline (1961-1990) data generated by PRECIS showed marked differences with actual (196190) data recorded at Anand station. So, the projected data were calculated considering actual data (1961-90) of Anand station. The difference between PRECIS baseline and $\mathrm{A}_{2}$ scenario was added to actual data of 1961-90 to get weather data for 2071-2100. Two approaches were adopted (i) day to day actual data of 1961-90 as baseline and (ii) daily normal (1961-90) as baseline. The crop model DSSAT 4.6 CROPGRO was used to study the mungbean crop response with the weather data generated using first approach i.e., day to day sum of actual weather data of 1961-90 and changes calculated using PRECIS baseline and $\mathrm{A}_{2}$ scenario projection data.

The grid wise data of maximum, minimum temperature and rainfall have been separated for different grid points of Anand district. Subsequently based on monthly mean, daily data were generated and used as $A_{2}$ scenario daily data for above mentioned parameters. The DSSAT 4.6 (CROPGRO) model was run for individual year using $\mathrm{A}_{2}$ scenario daily weather data for projected period for 2071 to 2100 AD.

The climate change projections for year 2071 2100 were made for Anand district using PRECIS output of $\mathrm{A}_{2}$ scenario and baseline (1961 to 1990) data. From monthly data to daily data were derived by regression interpolation method. DSSAT 4.6 (CROPGRO) model was used to study the crop response with the weather data generated using first approach i.e., day to day sum of actual weather data of 1961-90 and changes 
calculated using PRECIS baseline and $\mathrm{A}_{2}$ scenario projection data under impact analysis.

\section{Results and Discussion}

\section{Projected mean maximum temperature}

The annual mean maximum temperature as projected by PRECIS model output for period (2071-2100) for Anand with baseline data is presented in Table 1.

The results indicated that the mean maximum, minimum temperature and rainfall during baseline period were $33.2^{\circ} \mathrm{C}, 19.8{ }^{\circ} \mathrm{C}$ and $919.2 \mathrm{~mm}$ of Anand district while during projected period the maximum, minimum temperature and rainfall were $37.8^{\circ} \mathrm{C}, 24.1^{\circ} \mathrm{C}$ and $1312.0 \mathrm{~mm}$, respectively. The PRECIS outputs for the $A_{2^{-}}$scenarios (2071-2100) indicated that the mean maximum, minimum temperature and rainfall are expected to increase by 4.6 to $4.3{ }^{0} \mathrm{C}$ and $402 \mathrm{~mm}$ respectively at Anand district. Aggarwal et al., (2009) also reported increase in temperature under Indo Gangetic Plan Zone of Uttar Pradesh.

\section{Impact of projected climate on mungbean production at Anand}

The PRECIS model generated monthly data of minimum, maximum temperature and rainfall obtained from IITM Pune converted to daily data as per methodology described in Chapter3. The quantification of the impact of projected changes in climatic parameter such as atmospheric $\mathrm{CO}_{2}$, temperature and rainfall on mungbean crop production was assessed using validated DSSAT4.6 (CROPGRO) model for Anand districts of Gujarat. The normal daily BSS data was used in the model. The DSSAT (CROPGRO) model was used to simulate the phenology and yield and yield attributes using daily data of baseline (19611990) and projected period (2071-2100).
Possible effects of climate change on plant growth were evaluated using the crop growth simulation model. Projected $\mathrm{CO}_{2}$ concentration and temperature projections were applied as climate change study. The effect of climate change as obtained through simulated model in terms of days to attain anthesis and physiological maturity, grain yield and biomass yield are compared with that obtained from baseline period data and the percent change are reported and described in following section.

\section{Impact on days to anthesis of mungbean}

The anthesis days of baseline period (1961-90) and projected periods (2071-2100) under $A_{2}$ scenario for Anand district for various irrigation levels, varieties and spacing are presented in Table 3 and per cent advancement at Anand districts under different treatments are presented in Figure 1.

The results presented in Table 3 show that during baseline (1961-90) period the days to anthesis in cultivar in different treatments ranged between 31 days in $\left(\mathrm{I}_{2} \mathrm{~V}_{2} \mathrm{~S}_{2}, \mathrm{I}_{3} \mathrm{~V}_{2} \mathrm{~S}_{2}\right)$ to 35 days (in $\mathrm{I}_{1} \mathrm{~V}_{1} \mathrm{~S}_{1}, \mathrm{I}_{1} \mathrm{~V}_{1} \mathrm{~S}_{2}, \mathrm{I}_{2} \mathrm{~V}_{1} \mathrm{~S}_{1}, \mathrm{I}_{3} \mathrm{~V}_{1} \mathrm{~S}_{1}$ and $\mathrm{I}_{3} \mathrm{~V}_{1} \mathrm{~S}_{2}$ ) with mean anthesis days of 33.6 over the treatments. The days to anthesis simulated during projected period (2071-2100) ranged between 26 days (in $\mathrm{I}_{3} \mathrm{~V}_{2} \mathrm{~S}_{2}$ ) to 33 days (in $\mathrm{I}_{1} \mathrm{~V}_{1} \mathrm{~S}_{1}$ and $\mathrm{I}_{3} \mathrm{~V}_{1} \mathrm{~S}_{1}$ ) with mean anthesis days of 30.2 days (Table 3 ). The advancement in anthesis days due to impact of climate change ranged between 5.7 percent ( 2 days) to 16.1 per cent ( 5 days) in different treatments. The highest advancement in days to anthesis was projected in $\mathrm{I}_{3} \mathrm{~V}_{2} \mathrm{~S}_{2}$ treatment and lowest was projected in $I_{1} V_{1} S_{1}$ treatment, while mean advancement in days to anthesis in various treatment of green gram was 10.3 per cent (3.4 days) (Fig. 3).

It may be concluded that due to climate change the duration of days to anthesis are 
projected to be reduced, in all treatments of mungbean. However the reduction may be highest $(16.1 \%)$ in treatment $\mathrm{I}_{3} \mathrm{~V}_{2} \mathrm{~S}_{2}$ and lowest $(5.7 \%)$ in treatment $\mathrm{I}_{1} \mathrm{~V}_{1} \mathrm{~S}_{1}$. It might be due to Meha cultivar is temperature tolerant as compared to GM-2.

\section{Impact on days first pod}

The First pod days of baseline period (196190) and projected periods (2071-2100) under $A_{2}$ scenario for Anand district for various irrigation levels, varieties and spacing are presented in Table 3 and per cent advancement at Anand districts under different treatments are presented in Figure 1.

The results presented in Table 3 showed that during baseline (1961-90) period the days to First pod days in cultivar in different treatments ranged between 34 days $\left(\mathrm{I}_{1} \mathrm{~V}_{2} \mathrm{~S}_{1}\right.$, $\mathrm{I}_{2} \mathrm{~V}_{2} \mathrm{~S}_{2}, \mathrm{I}_{1} \mathrm{~V}_{2} \mathrm{~S}_{2}, \mathrm{I}_{2} \mathrm{~V}_{2} \mathrm{~S}_{1}$ and $\mathrm{I}_{3} \mathrm{~V}_{2} \mathrm{~S}_{2}$ ) to 37 days $\left(\mathrm{I}_{1} \mathrm{~V}_{1} \mathrm{~S}_{1}, \mathrm{I}_{1} \mathrm{~V}_{1} \mathrm{~S}_{2}, \mathrm{I}_{2} \mathrm{~V}_{1} \mathrm{~S}_{1}, \mathrm{I}_{3} \mathrm{~V}_{1} \mathrm{~S}_{1}\right.$ and $\left.\mathrm{I}_{3} \mathrm{~V}_{1} \mathrm{~S}_{2}\right)$ with mean First pod days of 33.7 over the treatments. The days to first pod days simulated during projected period (2071-2100) ranged between 29 days $\left(\mathrm{I}_{1} \mathrm{~V}_{2} \mathrm{~S}_{1}, \mathrm{I}_{1} \mathrm{~V}_{2} \mathrm{~S}_{2}\right.$ and $\left.\mathrm{I}_{2} \mathrm{~V}_{2} \mathrm{~S}_{1}\right)$ to 35 days $\left(\mathrm{I}_{1} \mathrm{~V}_{1} \mathrm{~S}_{2}\right)$ with mean first pod days of 31.5 days (Table 3). The advancement in first pod days due to impact of climate change ranged between 5.4 percent ( 2 days) and 14.5 per cent (05 days) in different treatments. The highest advancement in days to first pod days was projected in $\mathrm{I}_{1} \mathrm{~V}_{1} \mathrm{~S}_{1}$ and $\mathrm{I}_{1} \mathrm{~V}_{1} \mathrm{~S}_{1}$ treatment and lowest was projected in $\mathrm{I}_{1} \mathrm{~V}_{1} \mathrm{~S}_{2}$ treatment, while mean advancement in days to first pod days in various treatment of green gram was 11.7 per cent (4.2 days) (Fig. 1).

\section{Impact on first seed days}

The First seed days of baseline period (196190) and projected periods (2071-2100) under $\mathrm{A}_{2}$ scenario for Anand district for various irrigation levels, varieties and spacing are presented in Table 3 and per cent advancement at Anand districts under different treatments are presented in Figure 1.

The results presented in Table 3 showed that during baseline (1961-90) period the days to first seed days in cultivar in different treatments ranged between 39 days to 42 days with mean first seed days of 40.5 over the treatments. The days to first seed days simulated during projected period (2071-2100) ranged between 32 days (in $\mathrm{I}_{3} \mathrm{~V}_{2} \mathrm{~S}_{2}$ ) to 38 days (in $\mathrm{I}_{1} \mathrm{~V}_{1} \mathrm{~S}_{2}$ ) with mean first pod days of 34.7 days (Table 3). The advancement in first seed days due to impact of climate change ranged between 9.5 percent (4 days) to 17.9 per cent (07 days) in different treatments. The highest advancement in days to first seed days was projected in $\mathrm{I}_{3} \mathrm{~V}_{2} \mathrm{~S}_{2}$ treatment and lowest was projected in $I_{1} V_{1} S_{2}$ treatment, while mean advancement in days to first seed days in various treatment of green gram was 14.4 per cent (5.8 days) (Fig. 1).

\section{Impact on days to Physiological maturity}

The days to physiological maturity of baseline period (1961-90) and projected periods (20712100) under $A_{2}$ scenario for Anand district for various irrigation levels, varieties and spacing are presented in Table 4 and per cent advancement at Anand districts under different treatments are presented in Figure 1.

The results presented in Table 4 showed that during baseline (1961-90) period the days to days to physiological maturity in cultivar in different treatments ranged between 63 days $\left(\mathrm{I}_{3} \mathrm{~V}_{2} \mathrm{~S}_{2}\right)$ to 76 days $\left(\mathrm{I}_{1} \mathrm{~V}_{1} \mathrm{~S}_{1}\right.$ and $\left.\mathrm{I}_{1} \mathrm{~V}_{1} \mathrm{~S}_{2}\right)$ with mean days to physiological maturity days of 69.8 over the treatments. The days to physiological maturity simulated during projected period (2071-2100) ranged between 48 days $\left(\mathrm{I}_{3} \mathrm{~V}_{2} \mathrm{~S}_{2}\right)$ to 68 days $\left(\mathrm{I}_{1} \mathrm{~V}_{1} \mathrm{~S}_{2}\right)$ with mean days to physiological maturity of 57.1 days (Table 4). 
Table.1 Trend statistics and slopes of maximum temperature for Anand

\begin{tabular}{l|l|c|c|c|c|} 
Parameter & Period/season & \multicolumn{2}{|c|}{ Thil-Sen analysis } & \multicolumn{2}{c|}{ Regression analysis } \\
\cline { 2 - 7 } & & Slope & Kendall's tau & Slope & $\mathbf{R}^{\mathbf{2}}$ \\
\hline $\begin{array}{l}\text { Maximum } \\
\text { temp. }\end{array}$ & Winter & 0.030 & 0.290 & 0.033 & $\mathbf{0 . 1 2 0}$ \\
& Summer & 0.017 & 0.110 & 0.043 & $\mathbf{0 . 1 1 0}$ \\
& Monsoon & $0.016 \mathrm{c}$ & 0.169 & 0.019 & $\mathbf{0 . 0 7 0}$ \\
& Post-monsoon & $0.039 \mathrm{a}$ & 0.310 & 0.049 & $\mathbf{0 . 2 2 0}$ \\
& Annual & $0.027 \mathrm{a}$ & 0.350 & 0.033 & $\mathbf{0 . 2 4 0}$ \\
\hline $\begin{array}{l}\text { Minimum } \\
\text { temp. }\end{array}$ & Winter & $0.017 \mathrm{~b}$ & 0.220 & 0.020 & $\mathbf{0 . 1 2 0}$ \\
& Summer & $0.027 \mathrm{a}$ & 0.32 & 0.043 & $\mathbf{0 . 1 1}$ \\
& Monsoon & $0.017 \mathrm{a}$ & 0.36 & 0.019 & $\mathbf{0 . 0 7}$ \\
& Post-monsoon & $0.025 \mathrm{~b}$ & 0.22 & 0.029 & $\mathbf{0 . 1 1}$ \\
\hline Rainfall & Annual & $0.024 \mathrm{a}$ & 0.44 & 0.024 & $\mathbf{0 . 4 1}$ \\
\hline
\end{tabular}

Table.2 Baseline and Projected mean maximum, minimum temperature and rainfall at Anand during crop growth period ( $1^{\text {st }}$ March to $31^{\text {st }}$ May)

\begin{tabular}{|c|c|c|c|c|}
\hline S. No & Climatic parameters & $\begin{array}{c}\text { Baseline } \\
(1960-1990)\end{array}$ & $\begin{array}{c}\text { Scenario } \\
(2071-2100)\end{array}$ & $\begin{array}{l}\text { Change in } \\
\text { parameters }\end{array}$ \\
\hline 1 & $\mathrm{CO}_{2}$ Concentration(ppm) & 330 & 724.9 & 394.9 \\
\hline 2 & Maximum Temperature $\left({ }^{\circ} \mathrm{C}\right)$ & 33.2 & 37.8 & 4.6 \\
\hline 3 & Minimum Temperature $\left({ }^{0} \mathrm{C}\right)$ & 19.8 & 24.1 & 4.3 \\
\hline 4 & Rainfall (mm) & 4 & 6.2 & 2.2 \\
\hline
\end{tabular}

Table.3 Baseline (B) and Projected (P) days to anthesis, first pod days and first seed days under various treatments at Anand district of Gujarat

\begin{tabular}{|c|c|c|c|c|c|c|}
\hline \multirow[t]{2}{*}{ Treatments } & \multicolumn{2}{|c|}{ Anthesis } & \multicolumn{2}{|c|}{ First pod day } & \multicolumn{2}{|c|}{ Fist seed day } \\
\hline & Baseline & Projected & Baseline & Projected & Baseline & Projected \\
\hline $\mathbf{I} 1 V_{1} S_{1}$ & 35 & 33 & 37 & 34 & 42 & 36 \\
\hline$I_{1} V_{1} S_{2}$ & 35 & 32 & 37 & 35 & 42 & 38 \\
\hline $\mathrm{I}_{1} \mathrm{~V}_{2} \mathrm{~S}_{1}$ & 33 & 31 & 34 & 29 & 39 & 35 \\
\hline $\mathrm{I}_{1} \mathrm{~V}_{2} \mathrm{~S}_{2}$ & 33 & 32 & 34 & 29 & 39 & 34 \\
\hline $\mathbf{I}_{2} \mathbf{V}_{1} \mathbf{S}_{1}$ & 35 & 31 & 37 & 32 & 42 & 35 \\
\hline $\mathbf{I}_{2} \mathrm{~V}_{1} \mathrm{~S}_{2}$ & 34 & 29 & 37 & 33 & 42 & 36 \\
\hline $\mathrm{I}_{2} \mathrm{~V}_{2} \mathrm{~S}_{1}$ & 32 & 28 & 34 & 29 & 39 & 34 \\
\hline $\mathbf{I}_{2} \mathbf{V}_{2} \mathbf{S}_{2}$ & 31 & 27 & 34 & 31 & 39 & 33 \\
\hline $\mathbf{I}_{3} \mathbf{V}_{1} \mathbf{S}_{1}$ & 35 & 33 & 37 & 32 & 42 & 35 \\
\hline $\mathbf{I}_{3} \mathbf{V}_{1} \mathbf{S}_{2}$ & 35 & 31 & 37 & 32 & 42 & 34 \\
\hline $\mathbf{I}_{3} \mathbf{V}_{2} \mathrm{~S}_{1}$ & 33 & 29 & 36 & 32 & 39 & 34 \\
\hline $\mathrm{I}_{3} \mathrm{~V}_{2} \mathrm{~S}_{2}$ & 31 & 26 & 34 & 30 & 39 & 32 \\
\hline Mean & 33.6 & 30.2 & 35.7 & 31.5 & 40.5 & 34.7 \\
\hline
\end{tabular}

Where, $\mathrm{I}_{1^{-}} 0.8 \mathrm{IW} / \mathrm{CPE}$ ratio, $\mathrm{I}_{2^{-}} 0.6 \mathrm{IW} / \mathrm{CPE}$ ratio, $\mathrm{I}_{3^{-}} 0.4 \mathrm{IW} / \mathrm{CPE}$ ratio, $\mathrm{V}_{1^{-}}$Meha, $\mathrm{V}_{2^{-}} \mathrm{GM}-4, \mathrm{~S}_{1^{-}} 45 \mathrm{~cm}$ row to row spacing $\mathrm{S}_{2^{-}} 30 \mathrm{~cm}$ row to row spacing. 
Table.4 Baseline (B) and Projected (P) days to Physiological maturity, Maximum LAI and Numbers of podm ${ }^{-2}$ under various treatments at Anand

\begin{tabular}{|c|c|c|c|c|c|c|}
\hline \multirow[t]{2}{*}{ Treatments } & \multicolumn{2}{|c|}{ Physiological maturity } & \multicolumn{2}{|c|}{ Maximum LAI } & \multicolumn{2}{|c|}{ Numbers of $\mathrm{pod} / \mathrm{m}^{2}$} \\
\hline & Baseline & Projected & Baseline & Projected & Baseline & Projected \\
\hline $\mathbf{I}_{1} \mathbf{V}_{1} \mathbf{S}_{1}$ & 76 & 65 & 4.1 & 3.5 & 711 & 630 \\
\hline$\overline{I_{1} V_{1} S_{2}}$ & 76 & 68 & 4.8 & 4.2 & 756 & 687 \\
\hline $\mathbf{I}_{1} \mathbf{V}_{2} \mathrm{~S}_{1}$ & 67 & 58 & 3.8 & 3.1 & 465 & 400 \\
\hline $\mathbf{I}_{1} \mathbf{V}_{2} \mathbf{S}_{2}$ & 67 & 55 & 4.1 & 3.5 & 565 & 485 \\
\hline $\mathrm{I}_{2} \mathrm{~V}_{1} \mathrm{~S}_{1}$ & 75 & 59 & 3.7 & 3.1 & 562 & 485 \\
\hline $\mathrm{I}_{2} \mathrm{~V}_{1} \mathrm{~S}_{2}$ & 74 & 58 & 4.4 & 3.5 & 421 & 380 \\
\hline $\mathbf{I}_{2} \mathbf{V}_{2} \mathbf{S}_{1}$ & 66 & 55 & 3.2 & 2.6 & 402 & 350 \\
\hline $\mathbf{I}_{2} \mathbf{V}_{2} \mathbf{S}_{2}$ & 65 & 54 & 3.6 & 3.0 & 400 & 340 \\
\hline$\overline{\mathrm{I}_{3} \mathrm{~V}_{1} \mathrm{~S}_{1}}$ & 73 & 54 & 3.1 & 2.6 & 375 & 310 \\
\hline $\mathrm{I}_{3} \mathrm{~V}_{1} \mathrm{~S}_{2}$ & 72 & 61 & 3.5 & 3.1 & 290 & 220 \\
\hline $\mathbf{I}_{3} \mathbf{V}_{2} \mathbf{S}_{1}$ & 64 & 50 & 2.3 & 2.0 & 280 & 231 \\
\hline$\overline{\mathrm{I}_{3} \mathrm{~V}_{2} \mathrm{~S}_{2}}$ & 63 & 48 & 2.8 & 2.3 & 200 & 154 \\
\hline Mean & 69.8 & 57.1 & 3.6 & 3.0 & 452.3 & 389.3 \\
\hline
\end{tabular}

Table.5 Baseline (B) and Projected (P) days to Physiological maturity, Maximum LAI and Numbers of podm ${ }^{-2}$ under various treatments at Anand

\begin{tabular}{|c|c|c|c|c|}
\hline \multirow[t]{2}{*}{ Treatments } & \multicolumn{2}{|c|}{ Yield } & \multicolumn{2}{|c|}{ Total above ground biomass } \\
\hline & Baseline & Projected & Baseline & Projected \\
\hline $\mathbf{I}_{1} \mathbf{V}_{1} \mathbf{S}_{1}$ & 1600 & 1410 & 4467 & 3854 \\
\hline$\overline{I_{1} V_{1} S_{2}}$ & 1610 & 1490 & 4891 & 4320 \\
\hline$\overline{I_{1} V_{2} S_{1}}$ & 1250 & 1100 & 4019 & 3400 \\
\hline$\overline{\mathbf{I}_{1} \mathbf{V}_{2} \mathbf{S}_{2}}$ & 1457 & 1200 & 4657 & 3841 \\
\hline $\mathbf{I}_{2} \mathbf{V}_{1} \mathbf{S}_{1}$ & 1348 & 1130 & 4164 & 3654 \\
\hline $\mathbf{I}_{2} \mathbf{V}_{1} \mathbf{S}_{2}$ & 1257 & 1085 & 4461 & 3710 \\
\hline $\mathbf{I}_{2} \mathbf{V}_{2} \mathbf{S}_{1}$ & 1146 & 987 & 3867 & 3200 \\
\hline $\mathbf{I}_{2} \mathbf{V}_{2} \mathbf{S}_{2}$ & 1117 & 960 & 4057 & 3210 \\
\hline$\overline{\mathbf{I}_{3} \mathbf{V}_{1} \mathbf{S}_{1}}$ & 923 & 780 & 2968 & 2415 \\
\hline$\overline{\mathbf{I}_{3} \mathbf{V}_{1} \mathbf{S}_{2}}$ & 673 & 530 & 3010 & 2521 \\
\hline$\overline{I_{3} V_{2} S_{1}}$ & 762 & 612 & 2676 & 2101 \\
\hline $\mathrm{I}_{3} \mathrm{~V}_{2} \mathrm{~S}_{2}$ & 572 & 480 & 2126 & 1654 \\
\hline Mean & 1142.9 & 980.3 & 3780.3 & 3156.7 \\
\hline
\end{tabular}


Fig.1 Impact of climate change under $\mathrm{A}_{2}$ scenario (2071-2100) as compared to baseline (196190) on days to anthesis, first pod and first seed under various treatments at Anand

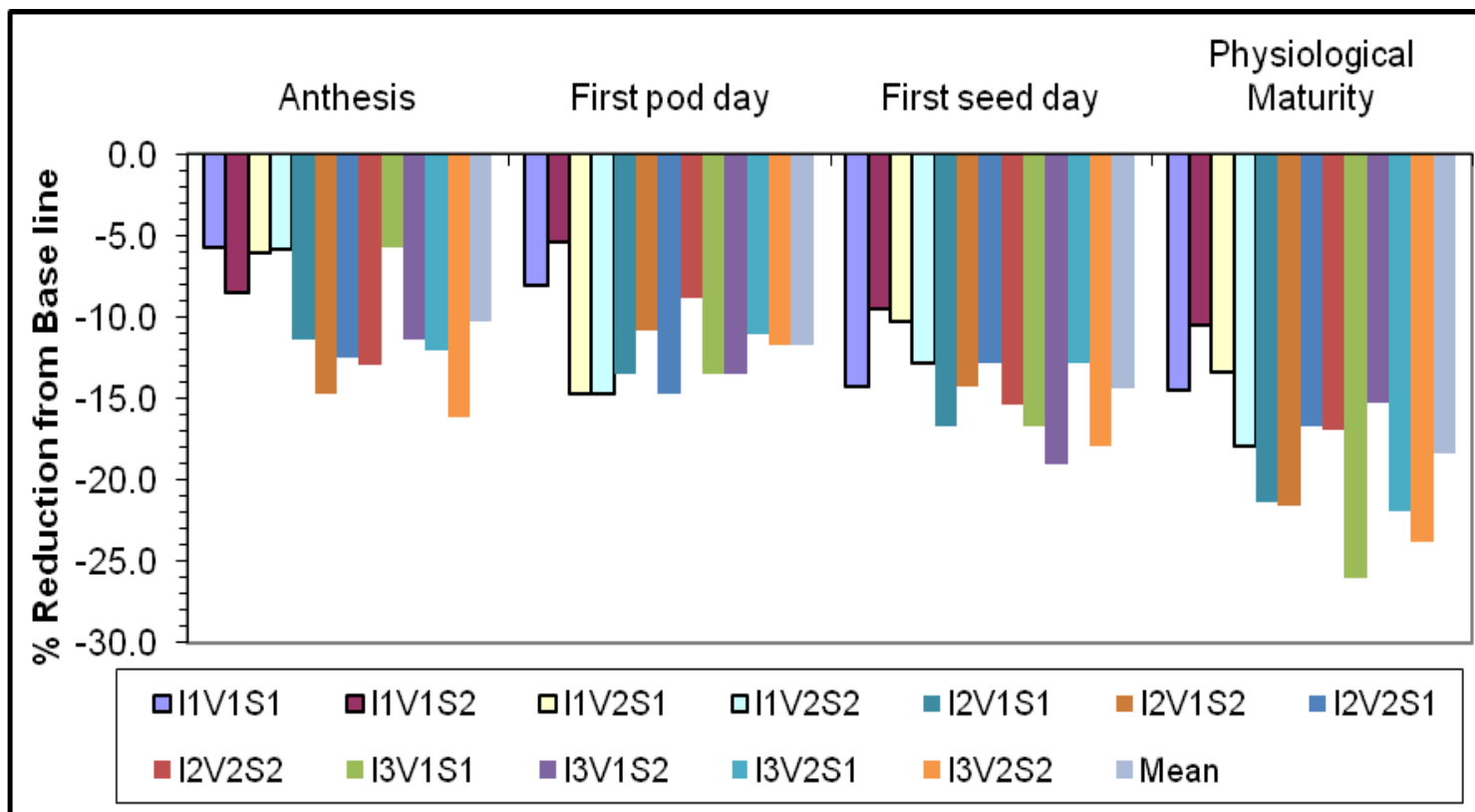

Fig.2 Impact of climate change under $A_{2}$ scenario (2071-2100) as compared to baseline (196190) on days to physiological maturity, maximum LAI, numbers of podm ${ }^{-2}$, yield and biomass under various treatments at Anand

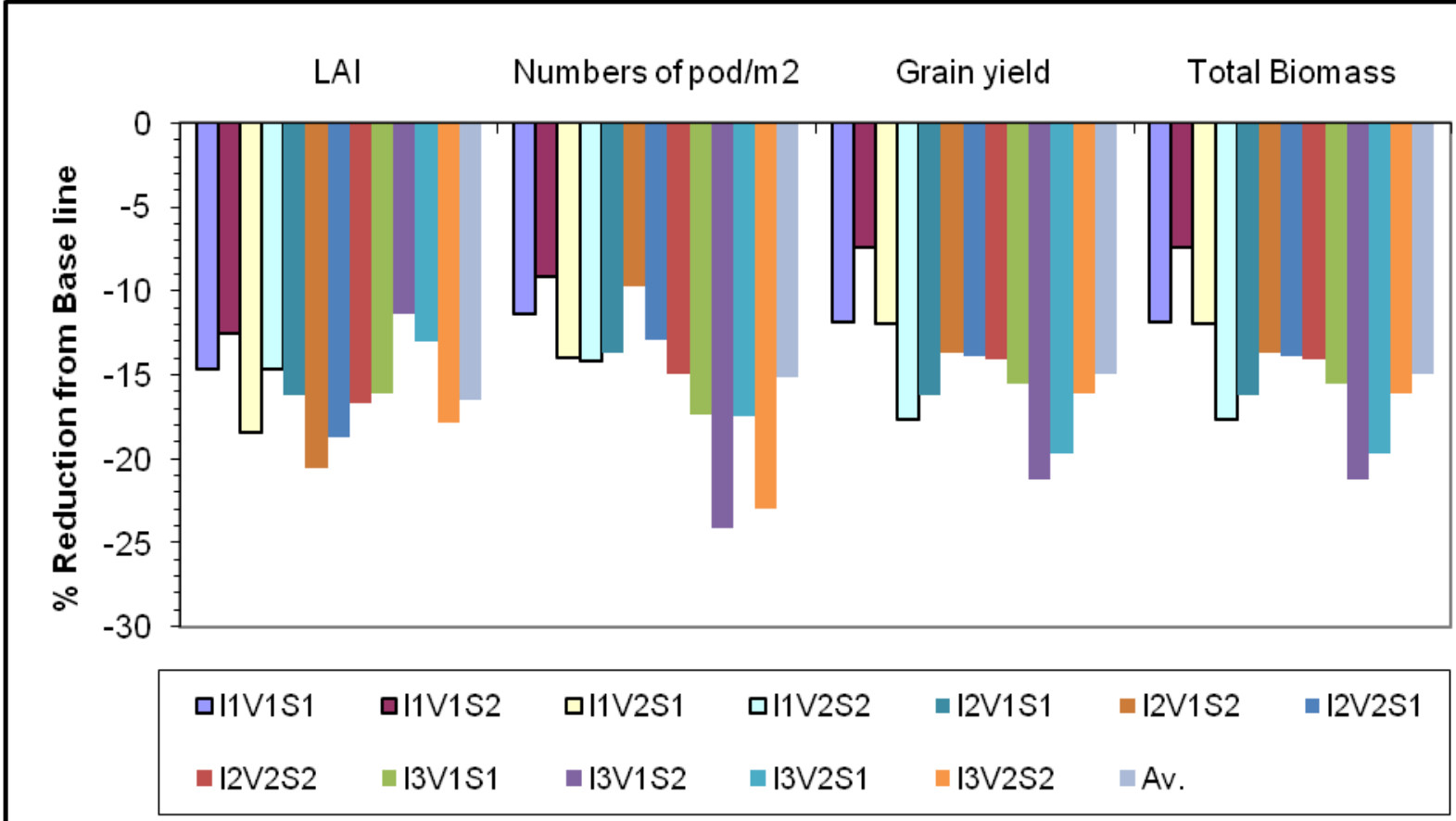


The advancement in days to physiological maturity due to impact of climate change ranged between 10.5 percent ( 8 days) to 23.8 per cent (15 days) in different treatments. The highest advancement in days to days to physiological maturity was projected in $\mathrm{I}_{3} \mathrm{~V}_{2} \mathrm{~S}_{2}$ treatment and lowest was projected in $\mathrm{I}_{1} \mathrm{~V}_{1} \mathrm{~S}_{2}$ treatment, while mean advancement in days to maturity in various treatment of green gram was 18.3 per cent (12.7 days) (Fig. 1).

It may be concluded that due to climate change the duration of days to physiological maturity are projected to be reduced, in all treatments of green gram. However the reduction may be highest $(23.8 \%)$ in treatment $\mathrm{I}_{3} \mathrm{~V}_{2} \mathrm{~S}_{2}$ and lowest $(10.5 \%)$ in treatment $\mathrm{I}_{1} \mathrm{~V}_{1} \mathrm{~S}_{2}$. It might be due to cv. Meha $\left(\mathrm{S}_{1}\right)$ is temperature tolerant as compared to $\mathrm{cv}$. GM $2\left(S_{2}\right)$. Pandey and Patel (2011) found similar result for maize and wheat at AAU, Anand.

\section{Impact on maximum LAI}

The days to maximum LAI of baseline period (1961-90) and projected periods (2071-2100) under $\mathrm{A}_{2}$ scenario for Anand district for various irrigation levels, varieties and spacing are presented in Table 4 and per cent reduction due to climate change during 2071$2100 \mathrm{AD}$ at Anand districts under different treatments are presented in Figure 2.

The results presented in Table 4 showed that during baseline (1961-90) period the maximum LAI in different treatments ranged between $2.8\left(\mathrm{I}_{3} \mathrm{~V}_{2} \mathrm{~S}_{2}\right)$ to $4.8\left(\mathrm{I}_{1} \mathrm{~V}_{1} \mathrm{~S}_{2}\right)$ with mean LAI of 3.6 over the treatments. The maximum LAI simulated during projected period (2071-2100) ranged between 2.0 (in $\mathrm{I}_{3} \mathrm{~V}_{2} \mathrm{~S}_{1}$ ) to 4.2 (in $\mathrm{I}_{1} \mathrm{~V}_{1} \mathrm{~S}_{2}$ ) with mean maximum LAI of 3.0 (Table 4 ). The reduction in maximum LAI due to impact of climate change ranged from $11.4 \%$ to $21.4 \%$ in different treatments of mungbean. The highest reduction in maximum LAI was projected in $\mathrm{I}_{3} \mathrm{~V}_{2} \mathrm{~S}_{2}$ treatment and lowest was projected in $\mathrm{I}_{3} \mathrm{~V}_{1} \mathrm{~S}_{2}$ treatment, while mean reduction in maximum LAI in various treatment of mungbean was $15.8 \%$.

It may be concluded that due to climate change the duration of maximum LAI are projected to be reduced, in all treatments of mungbean. However the reduction may be highest $(21.4 \%)$ in treatment $\mathrm{I}_{3} \mathrm{~V}_{2} \mathrm{~S}_{2}$ and lowest (11.4\%) in treatment $\mathrm{I}_{3} \mathrm{~V}_{1} \mathrm{~S}_{2}$.

\section{Impact on number of pods $\mathrm{m}^{-2}$}

The number of pods $\mathrm{m}^{-2}$ of mungbean in baseline period (1961-90) and projected periods (2071-2100) under $A_{2}$ scenario for Anand district for various irrigation levels, varieties and spacing are presented in Table 4 and per cent change in pods $\mathrm{m}^{-2}$ due to impact of climate change at Anand districts under different treatments are presented in Figure 2.

The DSSAT4.6 (CROPGRO) model simulated results showed that the number of pods $\mathrm{m}^{-2}$ during baseline period in different treatment ranged 200 pods $\mathrm{m}^{-2}\left(\mathrm{I}_{3} \mathrm{~V}_{2} \mathrm{~S}_{2}\right)$ to 756 pods $\mathrm{m}^{-2}\left(\mathrm{I}_{1} \mathrm{~V}_{1} \mathrm{~S}_{2}\right)$ with mean pods $\mathrm{m}^{-2}$ of 452.3 pods $\mathrm{m}^{-2}$, while the pods $\mathrm{m}^{-2}$ during projected period ranged between 154 pods $\mathrm{m}^{-2}\left(\mathrm{I}_{3} \mathrm{~V}_{2} \mathrm{~S}_{2}\right)$ to 687 pods $\mathrm{m}^{-2}\left(\mathrm{I}_{1} \mathrm{~V}_{1} \mathrm{~S}_{2}\right)$ with mean pods $\mathrm{m}^{-}$ ${ }^{2}$ of 389.3 pods $\mathrm{m}^{-2}$ (Table 4$)$. The reduction in pods $\mathrm{m}^{-2}$ due to impact of climate change ranged $9.1 \%$ to $24.1 \%$ in different treatments. The highest yield reduction was projected in $\mathrm{I}_{3} \mathrm{~V}_{1} \mathrm{~S}_{2}$ and lowest was projected in $\mathrm{I}_{1} \mathrm{~V}_{1} \mathrm{~S}_{2}$, while mean reduction in pods $\mathrm{m}^{-2}$ was $15.2 \%$ (Fig. 2).

\section{Impact on yield}

The grain yield of green gram under baseline period (1961-90) and projected periods (20712100) under $A_{2}$ scenario for Anand district for various irrigation levels, varieties and spacing 
are presented in Table 5 and per cent impacted by climate change during 20712100AD at Anand districts under different treatments are presented in Figure 2.

The DSSAT 4.6 (CROPGRO) model simulated results showed that the green gram yield during baseline period in different treatment ranged $572 \mathrm{kgha}^{-1}\left(\mathrm{I}_{3} \mathrm{~V}_{2} \mathrm{~S}_{2}\right)$ to 1610 $\mathrm{kgha}^{-1}\left(\mathrm{I}_{1} \mathrm{~V}_{1} \mathrm{~S}_{2}\right)$ with mean grain yield of $1142.9 \mathrm{kgha}^{-1}$, while the grain yield during projected period ranged between $480 \mathrm{kgha}^{-1}$ in $\left(\mathrm{I}_{3} \mathrm{~V}_{2} \mathrm{~S}_{2}\right)$ to $1480 \mathrm{kgha}^{-1}$ in $\left(\mathrm{I}_{1} \mathrm{~V}_{1} \mathrm{~S}_{2}\right)$ with mean grain yield during projected period was $980.3 \mathrm{kgha}^{-1}$ (Table 5). The grain yield reduction due to impact of climate change ranged 7.5 per cent to 21.3 per cent at different treatment. The highest yield reduction was projected in $\mathrm{I}_{3} \mathrm{~V}_{2} \mathrm{~S}_{2}$ and lowest was projected in $\mathrm{I}_{1} \mathrm{~V}_{1} \mathrm{~S}_{2}$, while mean yield reduction was $7.5 \%$ (Fig. 2).

The above mentioned results indicate that the highest grain yield reduction due to climate change under $\mathrm{I}_{3} \mathrm{~V}_{2} \mathrm{~S}_{2}$ in all treatments and lowest in $\mathrm{I}_{1} \mathrm{~V}_{1} \mathrm{~S}_{2}$ treatment. Aggarwal et al., (2010) and Kumar et al., (2012) also found similar result for wheat crop by model simulation.

\section{Impact on above ground biomass}

The above ground biomass of mungbean in baseline period (1961-90) and projected periods (2071-2100) under $A_{2}$ scenario for Anand district for various irrigation levels, varieties and spacing are presented in Table 5 and per cent impacted by climate change during 2071-2100 AD at Anand under different treatments are presented in Figure 2.

The DSSAT4.6 (CROPGRO) model simulated results showed that the mungbean above ground biomass during baseline period in different treatment ranged $2126 \mathrm{kgha}^{-1}$ $\left(\mathrm{I}_{3} \mathrm{~V}_{2} \mathrm{~S}_{2}\right)$ to $4891 \mathrm{kgha}^{-1}\left(\mathrm{I}_{1} \mathrm{~V}_{1} \mathrm{~S}_{2}\right)$ with mean above ground biomass of $3780 \mathrm{kgha}^{-1}$, while the above ground biomass during projected period ranged between $1654 \mathrm{kgha}^{-1}$ in $\left(\mathrm{I}_{3} \mathrm{~V}_{2} \mathrm{~S}_{2}\right)$ to $4320 \mathrm{kgha}^{-1}$ in $\left(\mathrm{I}_{1} \mathrm{~V}_{1} \mathrm{~S}_{2}\right)$ with mean above ground biomass during projected period was $3137 \mathrm{kgha}^{-1}$ (Table 5). The above ground biomass reduction due to impact of climate change ranged $11.7 \%$ to $22.2 \%$ in different treatments. The highest above ground biomass reduction was projected in $\mathrm{I}_{3} \mathrm{~V}_{2} \mathrm{~S}_{2}$ $(22.2 \%)$ and lowest was projected in $\mathrm{I}_{1} \mathrm{~V}_{1} \mathrm{~S}_{2}$ (11.7), while mean above ground biomass reduction was $17.0 \%$ (Fig. 2).

The above mentioned results indicate that the highest grain yield reduction due to climate change under $\mathrm{I}_{3} \mathrm{~V}_{2} \mathrm{~S}_{2}$ in all treatments and lowest in $\mathrm{I}_{1} \mathrm{~V}_{1} \mathrm{~S}_{2}$ treatment. Similar results were reported by Biyan et al., (2012) for mungbean. Aggarwal et al., (2010) Kumar et al., (2012), Yadav et al., (2012a) and Zagaria et al., (2014) reported similar results for wheat and Yadav et al., (2012b) for peanut crop by model simulation.

From the above discussion it is concluded that during the projected period (2071-2100 Ad) the $\mathrm{CO}_{2}$ concentration, maximum temperature, minimum temperature and rainfall will increase by $395 \mathrm{ppm}, 4.6^{\circ} \mathrm{C}, 4.3$ and $2.2 \mathrm{~mm}$, respectively compared to baseline (1960-1990 AD) climate. Hence, climate change will impact on summer mungbean production under middle Gujarat agroclimatic zone.

Under the climate change scenario due to higher maximum and minimum temperatures the days required to different phenological stages reduced by 2 to 5 days, 2 to 5 days, 4 to 7 days and 8 to 15 days to attain anthesis, first pod, first seed and physiological maturity under different treatments. The reduction may be highest $(23.8 \%)$ in treatment I3V2S2 and lowest $(10.5 \%)$ in treatment I1V1S2. It might be due to $\mathrm{cv}$. Meha is temperature tolerant as 
compared to GM 2. Similarly, reduction of 11.4 to $21.4,9.1$ to $24.1,7.5$ to 21.3 and 11.7 to $22.2 \%$ in maximum LAI, pods $\mathrm{m}-2$, grain yield and above ground biomass, respectively caused due to climate change during 20712100 AD compared to base line (1960-1990) period. Patel et al., (2015) found similar result for different rabi and kharif crop at AAU, Anand and Kadiyala et al., (2016) studied the impact of climate change on chickpea productivity at four locations and revealed that changes in temperature and rainfall by 2069 significantly $(\mathrm{p}<0.05)$ decreased the pod yield by $4.3,18.6,18$ and $17.2 \%$ at Anantapur, Kadapa, Kurnool and Prakasam district. Increasing the $\mathrm{CO}_{2}$ concentrations, pod yield was found to be increased by 11.6, 2.2, 0.8 and $17.2 \%$ at Anantapur, Kadapa, Kurnool and Prakasam districts.

From the above discussion it is concluded that during the projected period (2071-2100 Ad) the $\mathrm{CO} 2$ concentration, maximum temperature, minimum temperature and rainfall will increase by 395 ppm, 4.6 0C, 4.3 and $2.2 \mathrm{~mm}$, respectively compared to baseline (1960-1990 AD) climate. Hence, climate change will impact on summer mungbean production under middle Gujarat agroclimatic zone.

Under the climate change scenario due to higher maximum and minimum temperatures the days required to different phenological stages reduced by 2 to 5 days, 2 to 5 days, 4 to 7 days and 8 to 15 days to attain anthesis, first pod, first seed and physiological maturity under different treatments. The reduction may be highest $(23.8 \%)$ in treatment I3V2S2 and lowest $(10.5 \%)$ in treatment I1V1S2. It might be due to $\mathrm{cv}$. Meha is temperature tolerant as compared to GM 2. Similarly, reduction of 11.4 to $21.4,9.1$ to $24.1,7.5$ to 21.3 and 11.7 to $22.2 \%$ in maximum LAI, pods $\mathrm{m}-2$, grain yield and above ground biomass, respectively caused due to climate change during 2071-
2100 AD compared to base line (1960-1990) period. Patel et al., (2015) found similar result for different rabi and kharif crop at AAU, Anand

\section{References}

Aggarwal P. K. Singh A. K., Samra J.S., Singh G., Gogoi A.K., Rao, GGSN and Ramakrishna Y. S. (2009). Introduction. In Global Climate Change and Indian Agriculture, Ed: P.K. Aggarwal, ICAR, New Delhi, pp. 1-5.

Aggarwal, P. K., Katterkandi, B.; and Kumar, S.N. (2010). Mitigation. Adaptation. Global climate Change. 15: 413-431 pp.

Biyan, S. C., Basanti, C., Dhuppar, P. and Rao, D. S. (2012). Summer Mung Crop Production in the Context of Climate Change: An Appraisal. Indian Research Journal of Extension Education, Special Issue (2): 46-47.

Challinor, A. J. and Wheeler, T. R. (2008). Crop yield reduction in the tropics under climate change: Process and uncertainties. Agric. and Forest Meteorol. 148: 343-356.

Cline, W. R. (2008). Global Warming and Agriculture. Finance and Development (International Monetary Fund) 45 (1). Archived 17 August 2014.

Fu, T. Ha, B. and Ko, J. (2016). Simulation of $\mathrm{CO}_{2}$ enrichment and climate change impacts on soybean production. Int. Agrophy., 30: 25-37.

Kadiyala, M. D. M., Charyulu, K. D., Nedumaran, S., Shyam, M. D, Gumma, M. K. and Bantilan, M. C. S. (2016). Agronomic management options for sustaining chickpea yield under climate change scenario. J. Agromet., 18 (1): 41-47.

Kersebaum, K., Nendel, C. and Huth, N. I (2008). Site-specific impacts of climate change on wheat production across regions of Germany using different $\mathrm{CO}_{2}$ 
response functions. Eur. J. Agron., 52: 22-32.

Kumar, N., Tripathy, R. S., Jain, D. R.,Vishwakarma, A. K., Madhu, M., Rao, B. K., Tripathi, K. P. and Anurajan (2012) sensitivity of wheat crop to projected climate change in nontraditional areas. J. Agrometeorol, 14(1): 82-86.

Lobell, D., Burke, T. and Mastrandrea, F. N. (2008). Prioritizing climate change adaptation needs for food security in 2030. Science 319 (5863): 607-10.

Pandey V. and Patel H. R. (2011). Climate change and its impact on wheat and maize yield in Gujarat. In. Challenges and Opportunities in Agrometeorology (eds) S. D. Attri, L. S. Rathore, MVK Sivakumar, S.K.Dash. Springer. pp 321-334

Schneider, S. H. (2007). "19.3.2.1 Agriculture". In ML Parry, et al., (eds.). Chapter 19: Assessing Key Vulnerabilities and the Risk from Climate Change. Climate change 2007: impacts, adaptation and vulnerability: contribution of Working Group II to the fourth assessment report of the Intergovernmental Panel on Climate Change. Cambridge University Press (CUP): Cambridge, UK: Print version:
CUP. This version: IPCC website. p. 790

Singh, P., Nedumaran, S., Boote, K. J., Gaur, P. M. Srinivas, K. and Bantilan, M. C. S. (2014a). Climate change impacts and potential benefits of drought and heat tolerance in chickpea in South Asia and East Africa. Europ. J. Agron. 52 (B): 123-127.

Singh, P., Singh, N. P., Boote, K. J., Nedumaran, S., Srinivas, K. and Bantilan, M. C. (2014b). Management options to increase groundnut productivity under climate change at selected sites in India. J. Agromet., 16 (1): 52-59.

Yadav, S. B., Patel, H.R., Patel, G. G., Lunagaria, M. M., Karande, B. I., Shah, A. V. and Vandey, P. (2012b). Calibration and validation of PNUTGRO (DSSAT v4.5) model for yield and yield attributing characters of kharif groundnut cultivars in middle Gujarat region. J. Agrometeorol. 14: Special Issue, 24-29.

Yadav, S. B., Patel, H. R.; Kumar, A. and Pandey, V. (2012a). Impact assessment of climate change on wheat yield of middle Gujarat region. Int. J. Agri. Sci. \& Tech. 1 (1): 5-13.

\section{How to cite this article:}

Karande, B.I., H.R. Patel, S.B. Yadav, M.J. Vasani and Patil, D.D. 2018. Impact of Projected Climate Change on Summer Mungbean in Gujarat, India. Int.J.Curr.Microbiol.App.Sci. 7(08): 4178-4189. doi: https://doi.org/10.20546/ijcmas.2018.708.437 